\title{
Managing Team Selection to Win The World Cup
}

\author{
Jacob Donald Tan ${ }^{1}$, Ian Nurpatria Suryawan ${ }^{2}$, Richard Andrew ${ }^{3}$ \\ \{jacob.tan@uph.edu ${ }^{1}$, ian.nurpatria@gmail.com², richarda@fe.untar.ac.id $\left.{ }^{3}\right\}$ \\ Universitas Pelita Harapan, MH Thamrin Boulevard no.1, Tangerang, Banten ${ }^{1}$ \\ STIE Trisakti, Kyai Tapa no. 12, Tomang, Jakarta ${ }^{2}$ \\ Universitas Tarumanagara, Tanjung Duren Utara no.1, Grogol Petamburan, Jakarta ${ }^{3}$
}

\begin{abstract}
Managing team selection for the World Cup is as challenging as managing human resources in business. Currently only a few countries have won the World Cup in the biggest sporting event in the world. In fact, many countries today are yearning to win the World Cup. Managing team selection of the 23-man squad is pivotal and particularly when fielding the 11 players on the field. This research examined archives of World Cup teams from 1930-2018 to investigate the selections of players from their clubs to attain information whether fielding more players from the same soccer club impacted the probability to win the World Cup. The findings showed there is a pattern especially since World Cup 2006 that fielding more players from the same club determines a team's victorious destiny.
\end{abstract}

Keywords: football, world cup, management, teamwork, archival research

\section{Introduction}

According to [1], football is the most popular sport in the world that has an appeal not only for children and adolescents but also adults. This is also in line with the statement of [2] which states that sports, especially football in the $21^{\text {st }}$ century are growing rapidly thanks to the advancement of media technology globally. However, this rapid development does not necessarily increase the quality distribution of football teams throughout the world. This is evidenced by the lack of countries capable of winning the World Cup that only 8 of 211 FIFA member countries are able to achieve, while many countries are still eager to find their ways to win the World Cup.

According to [3], economic growth in the world plays an important role in professional football and some fundamental changes in it, especially those related to detailed information about the value of players. This is the reason there have been many similar 
studies carried out in the field of soccer management and business such as those conducted by [4] on leadership in football management, [5] on the implications of using foreign players in club football leagues, [6] about profit maximization and [7] about challenges in football management. Based on the background and results of the research presented by the previous experts, the researchers compiled the main objective of this study, namely to find a way to win the prestigious World Cup tournaments through the enhancement of team selections at the national team level. Therefore, in this study, the researchers will explore data from football world cup winners from time to time.

\section{Literature Review}

Sports management environment in the modern era includes five important things: quality, innovation, speed and flexibility, sustainable growth, and integrity [8]. Specifically in the human resources sector, however, sports management does not seem to have a significant focus in its strategic allocation of manpower, [9] emphasized that sports management requires deep involvement and knowledge of the sports, in addition to very broad qualifications that are not just basic managerial competencies.

To support good sports management, teamwork is essential. There is an indication of good teamwork resulting in the achievement of sports managerial goals, as good communication is required to galvanize the motivation of the team; in other words, a good work team is able to produce better performance [10]. [11] applied the statistical analysis to sixteen key performance indicators that are grouped into three categories: Goal-related indicators, Offensive-related indicators, and Defensive-related indicators. Their findings demonstrated that teams such as Spain and Italy (finalists of European Championship 2012) have greater performance consistency relative to other teams in terms of the key performance 
indicators, and Spain's performance consistency in some indicators contributed to the team being the Champion of Euro 2012.

\section{Methodology}

The researchers undertook archival research technique to delve into the historical data [12] of World Cup (WC) records from 1930-2018 to pinpoint the following four specific teams in each WC tournament: (i) The champion team, (ii) the runner-up team, (iii) the thirdplace team, and (iv) the worst performing team. First, the researchers group the players of each team based on the clubs they were playing in the particular year before the World Cup was held. Players that did not play for more than 90 minutes in the whole tournament are not included as their impact could be low. Second, the researchers enumerated the number of players playing for the same clubs in each of the four teams, and the results are shown as such in Table 1.1 - 1.2. Finally, pattern analysis is employed to examine the data as well as the irregularities that occurred to gain further insights.

\section{Analysis and Findings}

There are a total of 21 WC events being held between 1930-2018. In these events, only eight teams have had been champions: Uruguay, Italy, Germany, Brazil, England, Argentina, Spain, and France. As shown in Table $1.1-1.2$ the top three teams - the champion, the runner-up, the third place, as well as the worst team of each tournament are listed. The number of players selected from each club is also listed to analyze the patterns.

\subsection{Findings in the Champions Category (the most players from the same club)}

There are six (6) occurrences - 1930, 1982, 2006, 2010, 2014, and 2018 - the champion teams consisted of the most, if not, the same number of players in the same 
particular club when compared to the runner-up, third-place, and worst performing teams. In addition, there were three other (3) occasions - 1966, 1970, and 1998 - whereby the champion teams comprised of the most number of players from two different clubs. For instance in 1966 when England national team won the WC, three (3) players played for West Ham United and another three (3) for Manchester United. In 1970, when Brazil national team won the WC, three (3) players played for Santos FC and another three (3) for Botagfogo RJ. Then in 1998, when France national team won the WC, three (3) players played for AS Monaco and another three (3) for Marseille.

\subsection{Findings in the Runner-Up Category (the most players from the same club)}

There are five (5) occurrences - 1934, 1938, 1950, 1970, and 1994 - the runner-up teams consisted of the most players playing for the same club. In addition, there were three other (3) occasions - 1982, 1986, and 2002 - whereby the runner-up teams, West Germany and Germany, tried to field their players from two different main clubs in the country. For instance in 1982, when West Germany was a runner-up, three (3) players played for Hanburger SV and another three (3) for FC Koln. Italy, with six (6) national team players coming from Juventus, won the WC in that tournament. In 1986, when West Germany was runner-up again, three (3) players played for Bayern Munchen and another three (3) for FC Koln. In 2002 when Germany was a runner-up, four (4) players played for Bayern Munchen and another four (4) for Leverkusen.

\subsection{Findings in the Third-Place Category (the most players from the same club)}

In 1958 shown in Table 1.1, France was third-place with the most players from the same club among the top three teams in the tournament: five (5) players playing for Stade Reims. In 1962 shown in Table 1.1, Chile had the most players from the same club among the top three in the tournament: six (6) players playing for Universidad de Chile. In 1986, France 
had the most players from the same club among the top three in the tournament: four (4) players playing for Paris Saint Germain plus four (4) players playing for Girondins Bordeaux. In 1998, Croatia had the most players from the same club among the top three in the tournament: five (5) players playing for Croatia Zagreb. In 2006 shown in Table 1.2, Germany equaled having the most players from the same club with Champion Italy with four (4) players playing for Bayern Munchen. Champion Italy had four (4) players playing for AC Milan.

\subsection{Findings in the Worst Team Category (the most players from the same club)}

The researchers went further to inquire if the same phenomenon occurred for the worst team of each tournament by selecting the worst team based on its goal difference. Zurich club team (Switzerland) was National League A Champion in 1966, AS Vista Kinshasa (Zaire) was Linafoot League Champion in 1974 and 1975, Alianza Lima (Peru) was Peruvian Primera Division Champion in 1978, and Panathinaikos (Greece) was Greek Championship in 1994. This process of the investigation's outcomes is able to explain that despite the club teams being the best or one of the best in their specific country leagues, their skills, tactics, and systems are not on the same par with clubs from the top three teams in the WC tournament.

\subsection{Findings Summary}

Based on the data, top teams particularly West Germany and Germany, were known to use this specific tactic of selecting as many players from the same club, or if not, from two major clubs to compete in the WCs as shown in 1982 (West Germany), 1986 (West Germany), and 2002 (Germany). This tactic does not guarantee championships, nonetheless, it is a strategy worth striving for in major tournaments such as the WC. Other teams also attempted the same tactic and achieved top three ranking in the WC tournaments: Argentina $\left(2^{\text {nd }}\right.$ place in 
1930), England (Champion in 1966), Brazil (Champion in 1970), Poland ( ${ }^{\text {rd }}$ place in 1974),

France (Champion in 1998), Croatia ( $2^{\text {nd }}$ place in 2018), and Belgium ( ${ }^{\text {rd }}$ place in 2018).

Table 1.1: WC 1930 - 1962

\begin{tabular}{|c|c|c|c|c|c|c|}
\hline YEAR & The World Cup Champion & Runner-Up & Third-Place & Last & Wof Plavers from the same club & Club \\
\hline Host - Uruguay ${ }^{1930}$ & Uruguay & $\begin{array}{l}\text { A Argentina } \\
\text { Argentina }\end{array}$ & United States & Mexico (Table 1 GD -9 w o pts) & & $\begin{array}{l}\text { Nacional } \\
\text { Boca duniors } \\
\text { Estudiantil porteno } \\
\text { New York Nationals } \\
\text { CF Aftante }\end{array}$ \\
\hline Host - Italy 1934 & Italy & Czechoslovakia & Germany ur & ed States (1st round beaten by Italy & ${ }_{8}^{6}$ & $\begin{array}{l}\text { Juventus } \\
\text { SK Slaviva prahah } \\
\text { Dussevidorfer FK Fortuna } 1911 \\
\text { Pawtutucket r Fangers } \\
\text { fuller St. Louis }\end{array}$ \\
\hline Host - France ${ }^{1938}$ & Italy & Hungary & Brazil & Dutch East Indies & 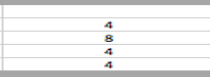 & $\begin{array}{l}\text { Inter } \\
\text { Fererncuaros } \\
\text { Fluminense RJ } \\
\text { Tiong Hoa Surabaja }\end{array}$ \\
\hline Host - Brazil 1950 & Uruguay & Brazil & Sweden & Bolivia & $\begin{array}{l}7 \\
8 \\
6 \\
5\end{array}$ & $\begin{array}{l}\text { CA Penarol } \\
\text { vasco da Gama } \\
\text { Malmo fF } \\
\text { Litoral }\end{array}$ \\
\hline $\begin{array}{l}1954 \\
\text { Host - Switzerland }\end{array}$ & West Germany & Hungary & Austria & South Korea & $\begin{array}{c}5 \\
4 \\
6 \\
13\end{array}$ & $\begin{array}{l}\text { FC Caiserslautern } \\
\text { Budagapestiv Voros Lobogo } \\
\text { Rapidi wien Clab } \\
\text { Seoul Army Club }\end{array}$ \\
\hline Host - Sweden ${ }^{1958}$ & Brazil & Sweden & France & Mexico & $\begin{array}{l}4 \\
2 \\
5 \\
5\end{array}$ & $\begin{array}{l}\text { Botaforo RJ } \\
\text { IfK Norrkoping } \\
\text { Stade Reims } \\
\text { Deportivo Guadalajara }\end{array}$ \\
\hline Host - Chile 1962 & Brazil & Czechoslovakia & chile & Switzerland & $\begin{array}{l}4 \\
5 \\
6 \\
4 \\
4\end{array}$ & $\begin{array}{l}\text { Santos FC } \\
\text { Dukkla Praha } \\
\text { Universidad de Chile } \\
\text { Lausanne Sports }\end{array}$ \\
\hline
\end{tabular}

Table 1.2: WC 2006 - 2018

\begin{tabular}{|c|c|c|c|c|c|c|}
\hline YEAR & The World Cup Champion & Runner - Up & Third-Place & Last & If of Players from the same club & Club \\
\hline Host - Germany 2006 & $\begin{array}{l}\text { Italy } \\
\text { Italy }\end{array}$ & France & Germany & Serbia and Montenegro & $\begin{array}{l}4 \\
3 \\
3 \\
4 \\
2\end{array}$ & $\begin{array}{l}\text { AC Milan } \\
\text { AS Roma } \\
\text { olymique Lyon } \\
\text { Bayern munchen } \\
\text { Partizan }\end{array}$ \\
\hline Host - Africa $\quad 2010$ & spain & Netherlands & Germany & North Korea & $\begin{array}{l}7 \\
2 \\
6 \\
4\end{array}$ & $\begin{array}{l}\text { FC Barcelona } \\
\text { Bavern Munchen } \\
\text { Bayern Munchen } \\
\text { Appri 25 }\end{array}$ \\
\hline Host - Brazil $\quad 2014$ & Germany & Argentina & Netherlands & Cameroon & $\begin{array}{l}6 \\
3 \\
4 \\
1\end{array}$ & $\begin{array}{l}\text { Bayern Munchen } \\
\text { Manchester City } \\
\text { Fevenoord } \\
\text { Diversified }\end{array}$ \\
\hline Host-Russia $\quad 2018$ & France & $\begin{array}{l}\text { Croatia } \\
\text { Croatia }\end{array}$ & $\begin{array}{l}\text { Belgium } \\
\text { Belgum } \\
\text { Belgium }\end{array}$ & Panama & $\begin{array}{l}3 \\
2 \\
2 \\
3 \\
3 \\
2 \\
2 \\
2\end{array}$ & $\begin{array}{l}\text { Atletica Madrid } \\
\text { Real Madrid } \\
\text { Inter } \\
\text { Tottenham Hotspur } \\
\text { Chelsea } \\
\text { Manchester United } \\
\text { New York RB } \\
\text { KaA Gork }\end{array}$ \\
\hline
\end{tabular}

\section{Implications and Conclusions}

One highlighted phenomenon that can be juxtaposed with this study's finding is the Brazilian national team that won the 2002 World Cup. The Brazilian players - that played more than 90 minutes in the tournament - each was coming from different clubs around the globe. Nevertheless since 2002, the Brazilian team had not been in the top three ranking for the past four WC events, hence experiencing a WC drought for more than 16 years. This might provide a notion that the findings of this study could be put into consideration for the Brazilian team, as besides quality players, teamwork is still key to winning major tournaments 
like the WC. The evidences of top team managers proceeding with their squad selections

(Table 1.2) by picking as many players from the same top club teams are denoted in the past four WC tournaments - 2006, 2010, 2014, and 2018 - with Italy, Spain, Germany, and France respectively.

Acknowledgments. The authors sincerely appreciate Universitas Pelita Harapan for the financial support that enables this article to be published and presented in the conference.

\section{References}

[1] Palacios-Huerta, I.: Structural changes during a century of the world's most popular sport, Statistical Methods and Applications, vol. 13, no. 2. pp. 241-258 (2004)

[2] Hamil, S. and Chadwick, S., "Managing football," An International Perspective (Elsevier: London) (2010)

[3] Frick, B.: The Football Players' Labor Market: Empirical Evidence From The Major European Leagues, Scottish Journal of Political Economy, vol. 54, no. 3. pp. 422-446 (2007)

[4] Crust, L. and Lawrence, I.: A review of leadership in sport: Implications for football management, Athletic Insight: The Online Journal of Sport Psychology, vol. 8, no. 4. pp. 28-48 (2006)

[5] Madichie, N. O.: Professional sports: a new, The Marketing Review, vol. 9, no. 4. pp. 301-318 (2009)

[6] Garcia-del-Barrio, P. and Szymanski, S.: Goal! Profit maximization versus win maximization in soccer, Review of Industrial Organization, vol. 34, no. 1. pp. 45-68 (2009)

[7] Darsana, M.: The influence of personality and organizational culture on employee performance through organizational citizenship behavior, The International Journal of Management, vol. 2, no. 4. pp. 35-42 (2013)

[8] Covell, D. and Walker, S.: Managing intercollegiate athletics. Routledge. (2019)

[9] Horch, H.-D. and Schütte, N.: Competencies of sport managers in German sport clubs and sport federations, Managing leisure, vol. 8, no. 2. pp. 70-84 (2003)

[10] Gershgoren, L., Basevitch, I., Gershgoren, A., Brill, Y. S., Schinke, R. J., and Tenenbaum, G.: Expertise in soccer teams: A thematic inquiry into the role of shared mental models within team chemistry, Psychology of Sport and Exercise, vol. 24. pp. 128-139 (2016)

[11] Shafizadeh, M., Taylor, M., and Peñas, C. L.: Performance consistency of international soccer teams in Euro 2012: A time series analysis, Journal of human kinetics, vol. 38. pp. 213-226 (2013)

[12] Ventresca, M. J. and Mohr, J. W.: Archival research methods, The Blackwell companion to organizations. pp. 805-828 (2017) 